\title{
Pengembangan Soal Literasi Matematis untuk Mendukung Matematisasi Mahasiswa Calon Guru
}

\author{
Lestariningsih $^{1^{*}}$, Moch. Lutfianto ${ }^{2}$ \\ ${ }^{1}$ Program Studi Pendidikan Matematika, STKIP PGRI Sidoarjo \\ ${ }^{2}$ Program Studi Pendidikan Matematika, STKIP Al Hikmah Surabaya \\ *lestari.med@gmail.com
}

\begin{abstract}
Abstrak
Kemampuan matematisasi mahasiswa calon guru yang rendah dalam menyelesaikan soal literasi matematis perlu mendapat perhatian yang serius. Oleh karena itu, untuk membantu mahasiswa calon guru dalam melakukan matematisasi, mereka dilatih dengan memberikan soal literasi matematis. Penelitian ini bertujuan untuk menghasilkan soal literasi matematis yang valid, praktis dan memiliki efek potensial terhadap kemampuan matematisasi mahasiswa calon guru. Penelitian dilakukan dengan menggunakan design research tipe development study. Sebanyak 34 mahasiswa calon guru dari perguruan tinggi swasta di Sidoarjo menjadi subjek penelitian. Soal literasi hasil pengembangan berupa soal yang dapat digunakan untuk mendukung mahasiswa calon guru dalam melakukan aktivitas matematisasi, baik horisontal maupun vertikal. Selain itu, soal tersebut didesain menggunakan kerangka Programme for International Student Assessment (PISA) dengan konteks Indonesia. Hasil penelitian menunjukkan soal literasi matematis yang dikembangkan dapat dikategorikan valid berdasarkan penilaian validator, praktis dari hasil ujicoba small group, serta memiliki efek potensial yang terlihat dari hasil tes yang diberikan setelah field test menggunakan soal literasi matematis. Berdasarkan hasil tes diketahui 78\% mahasiswa calon guru masuk kategori baik dalam matematisasi setelah menggunakan soal yang dikembangkan. Soal literasi matematis yang dikembangkan memiliki efek potensial sehingga bisa digunakan sebagai alternatif soal dalam kegiatan perkuliahan di perguruan tinggi untuk mendukung matematisasi mahasiswa calon guru.
\end{abstract}

Kata kunci: konteks Indonesia, mahasiswa calon guru, matematisasi, soal literasi matematis

\begin{abstract}
Mathematisation ability of prospective teachers that was low in solving mathematical literacy problems needs serious attention. Therefore, to help prospective teachers do mathematization, they were employed by giving mathematical literacy problems. This study aims to produce mathematical literacy problems that were valid, practical, and have potential effects on the mathematization ability of prospective teacher students. The study was conducted using a design research type development study. Thirty students of prospective teachers in a private university in Sidoarjo became the subjects. Mathematical literacy problems' qualities from this research should support prospective mathematics teachers in categorizing horizontal and verticalization activities. In addition, the problems were designed using the Program for International Student Assessment (PISA) framework with the Indonesian context. The results suggested that the developed mathematical literacy problems could be categorized valid based on validators' evaluation, practically based on the small group phase results, and have the potential effects were assessed from the results of student tests handed in field test phase using mathematical literacy problems. The test results showed that $78 \%$ of prospective mathematics teachers were in the good category of mathematization ability after using the developed problems. The developed mathematical literacy problem has a potential
\end{abstract}


effect so that it can be used as an alternative question in lecturing higher education activities to support the mathematics of prospective teacher students.

Keywords: Indonesian context, mathematical literacy problems, mathematisation, prospective mathematics teachers

Received: November 29, 2020 / Accepted: January 8, 2021 / Published Online: January 10, 2021

\section{Pendahuluan}

Matematisasi memiliki peranan yang sangat penting dalam menyelesaikan soal matematika terutama soal kontekstual (Lestariningsih, Amin, Lukito, \& Lutfianto, 2017, 2018a; Warsito, Darhim, \& Herman, 2018). Matematisasi digunakan ketika seseorang merumuskan permasalahan konteks dunia nyata (soal kontekstual) ke dalam soal matematis termasuk membuat model atau representasi matematis. Selain itu, matematisasi juga digunakan seseorang ketika mereka sedang menyelesaikan masalah dan menginterpretasikan solusi matematis yang diperoleh dalam konteks dunia nyata. Matematisasi merupakan aktivitas yang dilakukan oleh matematikawan dan pembelajar dalam memahami situasi atau masalah sehari-hari menggunakan pendekatan matematis (Lestariningsih, Amin, Lukito, \& Lutfianto, 2018b).

Menurut de Lange (1987) matematisasi dibedakan menjadi dua macam, yakni matematisasi horizontal dan matematisasi vertikal. Selanjutnya Gravemeijer (1994) menyatakan matematisasi horizontal sebagai aktivitas mengubah soal konteks dunia nyata ke dalam soal matematika, sedangkan matematisasi vertikal merupakan aktivitas memformulasikan soal matematika menjadi penyelesaian matematis dengan menerapkan sejumlah aturan yang sesuai dengan matematika. Kegiatan menafsirkan solusi matematis ke dalam konteks soal juga menjadi bagian dari matematisasi vertikal.

Sejalan dengan pendapat Gravemeijer (1994), dalam penelitian ini, matematisasi didefinisikan sebagai aktivitas mentransformasikan soal yang dinyatakan dengan konteks kehidupan nyata ke dalam model atau representasi matematis, kemudian penyelesaian model atau representasi matematis ditafsirkan ke dalam konteks kehidupan nyata. Berdasarkan definisi matematisasi yang digunakan dalam penelitian ini, maka disusun indikator matematisasi sebagai berikut: 1) mengidentifikasi aspek matematika yang diketahui dalam bentuk deskripsi verbal, 2) mengidenfikasi fakta, konsep, prinsip, atau prosedur yang terdapat dalam soal konteks dunia nyata, 3) memvisualisasikan fakta, konsep, prinsip, atau prosedur menggunakan pemodelan, 4) menggunakan atau membangun fakta, konsep, prinsip, atau prosedur atau penalaran matematis untuk memeroleh solusi matematis, 5) menafsirkan solusi matematis ke dalam konteks dunia nyata pada soal awal, 6) mengevaluasi kesesuaian antara solusi matematis dalam konteks masalah dunia nyata. 
Matematisasi merupakan kemampuan yang harus dimiliki oleh mahasiswa calon guru matematika karena matematisasi sudah menjadi bagian yang tidak terpisahkan dalam proses pembelajaran maupun proses menyelesaikan masalah dalam matematika (Biccard \& Wessels, 2015, 2017). Namun hasil penelitian Stillman dan Brown (2014) bahwa banyak individu yang mengalami kesulitan dalam melakukan matematisasi ketika menyelesaikan masalah kontekstual. Selanjutnya Winter (2013) menyatakan bahwa pengetahuan mahasiswa calon guru matematika di perguruan tinggi dalam memodelkan soal kontekstual dan menghubungkan konsep-konsep matematika yang terkait dengan soal (matematisasi) masih lemah. Sejalan dengan ini, hasil penelitian Patnani (2013) juga menunjukkan bahwa matematisasi mahasiswa calon guru dalam menyelesaikan soal masih rendah. Salah satu strategi untuk menghasilkan guru matematika yang mempunyai kompetensi yang baik dalam matematisasi adalah dengan mempersiapkan mereka sejak menjadi mahasiswa calon guru (Abdullah, 2015).

Hasil-hasil penelitian yang menunjukkan pentingnya matematisasi dan lemahnya kemampuan matematisasi mahasiswa calon guru (Abdullah, 2015; Biccard \& Wessels, 2015, 2017; Patnani, 2013; Stillman \& Brown, 2014; Winter, 2013) perlu mendapat perhatian yang serius bagi dunia pendidikan. Salah satu upaya yang bisa dilakukan sebagai tindak lanjut adalah mengembangkan instrumen literasi matematis. Pulungan (2014) melakukan penelitian tentang pengembangan instrumen tes literasi matematika model PISA. Dari penelitian, diketahui bahwa hasil validasi dari ahli menyatakan instrumen tes literasi matematika model PISA yang berada pada kategori baik. Kemudian Mahfudhoh, Susanto, dan Trapsilasiwi (2017) melakukan penelitian tentang pengembangan soal pelevelan literasi matematika konteks personal untuk siswa kelas VIII SMP. Hasil penelitian menunjukkan soal-soal yang dikembangkan termasuk soal yang reliabel.

Dalam penelitian ini, soal literasi matematis yang dikembangkan bertujuan untuk mendukung matematisasi mahasiswa calon guru yang mengacu pada kerangka PISA. Dengan demikian, diharapkan mahasiswa calon guru yang akan menjadi guru matematika terbiasa dengan bentuk-bentuk soal PISA sehingga mereka bisa membiasakan siswa ketika mengajar matematika.

\section{Metode}

Jenis penelitian design research tipe development study digunakan sebagai acuan dalam mengembangkan soal literasi matematis dalam penelitian ini. Subjek penelitian adalah 34 mahasiswa calon guru matematika semester tiga program studi pendidikan matematika di perguruan tinggi swasta di Sidoarjo pada tahun 2018 sampai 2020. Subjek penelitian terdiri 
atas 26 mahasiswa perempuan dan 8 mahasiswa laki-laki. Sebesar $65 \%$ dari subjek penelitian kuliah sambil bekerja dan 35\% mahasiswa belum bekerja. Kemudian kondisi sosial ekonomi subjek penelitian ini 32\% berada dalam kelompok ekonomi bawah, 51\% berada dalam kelompok ekonomi sedang, dan 17\% berada dalam kelompok ekonomi atas.

Penelitian pengembangan ini terdiri atas dua tahap, yaitu tahap preliminary study dan formative evaluation. Tahap formative evaluation meliputi self evaluation, prototyping (expert review, one-to-one, dan small group), serta field test (Tessmer, 1993; Zulkardi, 2006). Alur desain penelitian pengembangan tersebut ditunjukkan pada Gambar 1.

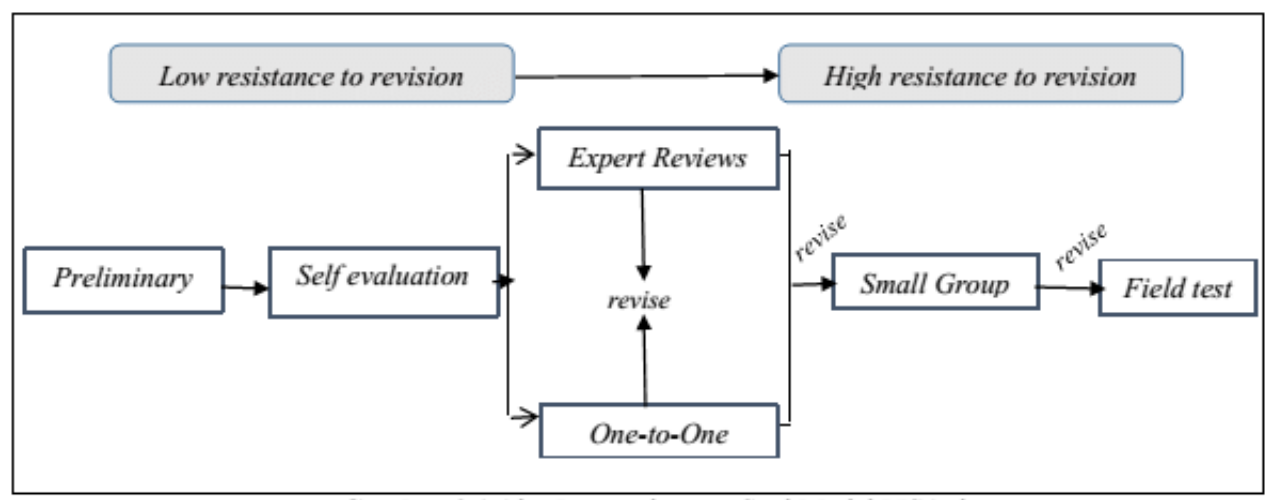

Gambar 1. Alur Desain Penelitian

Tahap preliminary study terdiri atas tiga tahap, yaitu persiapan, analisis, dan desain. Tahap persiapan dilakukan dengan menentukan tempat dan subjek penelitian. Tempat penelitian yang dipilih adalah perguruan tinggi swasta di Sidoarjo. Tahap analisis terdiri atas analisis mahasiswa calon guru, analisis kurikulum yang digunakan program studi pendidikan matematika, serta analisis materi. Selanjutnya tahap desain dilakukan dengan mendesain soal literasi matematis untuk mendukung matematisasi mahasiswa calon guru dengan menggunakan konteks khas Indonesia yang dirumuskan menjadi konteks pribadi, pekerjaan, sosial, dan sains. Untuk menyelesaikan soal tersebut, mahasiswa calon guru harus melakukan aktivitas matematisasi. Dalam menyelesaikan soal ini, seseorang perlu merumuskan, menggunakan, dan menafsirkan pengetahuan matematika dalam berbagai konteks. Soal literasi matematis menggunakan kerangka PISA dengan menggunakan konten, konteks, dan prediksi level soal. Tahap formative evaluation terdiri atas self-evaluation, prototyping (expert review, one-to-one, small group), dan field test.

Teknik pengumpulan dan analisis data dalam penelitian ini menggunakan walkthrough, observasi, wawancara, dan tes. Walkthourgh dilakukan untuk mendapatkan saran atau pendapat dari expert review untuk melihat kevalidan soal literasi matematis berdasarkan konten, konstruk dan bahasa guna menunjang matematisasi mahasiswa calon guru. Expert review pada penelitian 
ini dilakukan oleh lima orang dosen yang terdiri dari empat guru besar pendidikan matematika dan satu doktor matematika yang memiliki kepakaran dalam mengembangkan soal literasi matematis dan matematisasi. Kegiatan observasi dilakukan untuk mengetahui karakteristik dan kebutuhan mahasiswa calon guru pada tahap analisis, selanjutnya pada tahap evaluasi, observasi dilakukan untuk mengetahui gambaran tentang kepraktisan dari soal literasi matematis untuk mendukung matematisasi mahasiswa calon guru yang dikembangkan peneliti pada tahap small group. Kemudian observasi dilakukan pada tahap field test untuk melihat matematisasi mahasiswa calon guru dalam mengerjakan soal literasi matematis konteks khas Indonesia. Wawancara pada penelitian ini digunakan pada saat one-to-one, dan small group. Jenis wawancara yang dilakukan adalah wawancara tak terstruktur. Tes digunakan untuk melihat efek potensial terhadap matematisasi mahasiswa calon guru.

Indikator keberhasilan dalam pengembangan soal ini mencakup tiga aspek, yaitu valid, praktis, dan efektif atau memiliki efek potensial. Kevalidan soal literasi matematis tercapai jika hasil validasi pakar secara kualitatif dari aspek konten, konstruk dan bahasa minimal menyatakan baik. soal literasi matematis yang dikembangkan dikatakan praktis apabila memenuhi dua hal yaitu; (1) para pakar menyatakan bahwa soal literasi matematis yang dikembangkan dapat diterapkan dan (2) pada tahap small group, mahasiswa calon guru menyatakan dapat memahami maksud atau aspek-aspek yang ditanyakan dalam soal. Hal ini dapat juga diketahui dari hasil wawancara dengan mahasiswa calon guru. Selanjutnya, efektivitas soal literasi matematis dalam mendukung matematisasi mahasiswa calon guru dapat diukur dari hasil belajar mahasiswa calon guru dalam tahap field test dengan mengacu pada skor minimal untuk mendapatkan nilai baik (B) sesuai kurikulum yang berlaku di perguruan tinggi dengan mengacu pada kurikulum yang disusun oleh organisasi profesi, yaitu minimal 66.

\section{Hasil Penelitian}

Tahap preliminary study yang dilakukan dalam penelitian ini meliputi persiapan, analisis, dan desain. Dari kegiatan persiapan, dipilih satu perguruan tinggi swasta di Sidoarjo sebagai tempat penelitian, dan dipilih 34 mahasiswa calon guru matematika yang selanjutnya disebut mahasiswa calon guru sebagai subjek penelitian. Subjek penelitian adalah mahasiswa calon guru semester tiga. Untuk kurikulum, maka soal literasi matematis yang dikembangkan dapat digunakan dalam mata kuliah matematika sekolah dan mata kuliah problem solving. Soal literasi matematis yang dikembangkan terdiri atas dua soal dengan konteks pekerjaan, empat soal dengan konteks pribadi, empat soal dengan konteks sains, dan dua soal dengan konteks sosial. Soal literasi matematis dengan level tiga ada empat soal, level empat ada empat soal, 
level lima dan enam masing-masing ada 2 soal. Kevalidan soal literasi matematis diketahui berdasarkan hasil penilaian validator, kepraktisan dari hasil uji coba small group. Aspek konteks, konten, prediksi level soal, dan proses matematis (mathematical process) yang terdapat dalam soal literasi matematis disajikan dalam Tabel 1.

Tabel 1. Aspek konteks, konten, prediksi level soal, dan proses matematis

\begin{tabular}{cllcl}
\hline $\begin{array}{c}\text { No } \\
\text { Soal }\end{array}$ & Konteks & \multicolumn{1}{c}{ Konten } & $\begin{array}{c}\text { Prediksi } \\
\text { Level }\end{array}$ & \multicolumn{1}{c}{ Proses Matematis } \\
\hline 1 & pekerjaan & kuantitas & 3 & formulate, employ, \& interpret \\
2 & pribadi & bentuk dan ruang & 4 & formulate, employ, \& interpret \\
3 & sains & perubahan dan hubungan & 3 & formulate, employ, \& interpret \\
4 & pribadi & ketidakpastian dan data & 4 & formulate, employ, \& interpret \\
5 & sosial & ketidakpastian dan data & 5 & formulate, employ, \& interpret \\
6 & sains & bentuk dan ruang & 6 & formulate, employ, \& interpret \\
7 & pekerjaan & kuantitas & 3 & formulate, employ, \& interpret \\
8 & pribadi & bentuk dan ruang & 4 & formulate, employ, \& interpret \\
9 & sains & perubahan dan hubungan & 3 & formulate, employ, \& interpret \\
10 & pribadi & ketidakpastian dan data & 4 & formulate, employ, \& interpret \\
11 & sosial & ketidakpastian dan data & 5 & formulate, employ, \& interpret \\
12 & sains & bentuk dan ruang & 6 & formulate, employ, \& interpret \\
\hline
\end{tabular}

Selanjutnya tahap pertama dari formative evaluation adalah self-evaluation. Pada tahap self-evaluation, diperoleh soal literasi matematis yang dikembangkan menggunakan konteks khas Indonesia. Penggunaan kalimat matematika dan rumusan soal yang benar, penggunaan kaidah Bahasa Indonesia yang baik dan benar, dan konten dalam soal dapat mendukung matematisasi mahasiswa calon guru. Hasil dari tahap ini disebut prototipe 1.

Prototipe 1 yang dihasilkan dari self-evaluation kemudian divalidasi oleh ahli (expert). Tahap expert review dilakukan untuk melihat kevalidan soal literasi matematis yang dikembangkan dilihat dari konten, konstruk, dan muka. Validitas isi pada soal literasi matematis meliputi ketepatan atau kesesuaian materi soal yang digunakan dengan karakteristik soal literasi matematis yang dalam penelitian ini mengacu pada kerangka PISA. Konten yang digunakan adalah kuantitas, bentuk dan ruang, perubahan dan hubungan, dan ketidakpastian dan data. Sedangkan konteks soal yang dipakai meliputi pekerjaan, pribadi, sains, dan sosial. Kemudian prediksi level dalam soal literasi mulai dari 3, 4, 5, dan 6. Validitas konstruk terkait dengan konstruksi bidang ilmu yang digunakan dalam soal literasi matematis. Validitas konstruk dilakukan dengan melihat kesesuaian soal literasi matematis dalam mendukung matematisasi mahasiswa calon guru. Selanjutnya validitas muka ditentukan dengan cara menelaah butir-butir soal untuk menjamin bahwa soal tersebut sesuai dengan kaidah penulisan butir, konstruk, materi yang diukur, dan rumusan soal menggunakan kalimat matematika yang benar, memakai 
kaidah bahasa Indonesia yang baik dan benar, menggunakan kata-kata yang dikenal mahasiswa dan rumusan soal komunikatif.

Sementara itu, peneliti juga melakukan uji coba one-to-one beriringan dengan pelaksanaan expert review. One-to-one bertujuan untuk melihat kejelasan bahasa dari soal serta kesulitan-kesulitan mahasiswa calon guru dalam menyelesaikan setiap soal yang dikembangkan. Komentar dan saran dari mahasiswa calon guru serta kesulitan-kesulitan yang mereka hadapi ketika menyelesaikan soal digunakan sebagai bahan untuk mmemperbaiki soal literasi matematis yang dikembangkan. Hasil validasi dalam tahap expert reviews dan one-toone dapat dilihat dalam Tabel 2. Soal literasi matematis hasil perbaikan yang telah memenuhi kriteria valid disebut prototipe 2 .

Tabel 2. Hasil validasi dalam tahap expert reviews

\begin{tabular}{|c|c|c|}
\hline No & Komentar/Saran Perbaikan & Keputusan Revisi \\
\hline 1 & $\begin{array}{l}\text { Sebaiknya ditambahkan cover, sehingga } \\
\text { soalnya tidak langsung terlihat (reviewer } \\
\text { 1) }\end{array}$ & Menambahkan cover pada soal \\
\hline \multirow[t]{3}{*}{2} & $\begin{array}{l}\text { Pada soal nomor } 1 \text {, penulisan mata uang } \\
\text { Indonesia } \\
\text { menggunakan spasi setelah huruf "p" }\end{array}$ & $\begin{array}{l}\text { Menghilangkan spasi yang ada setelah } \\
\text { huruf "p" pada "Rp" }\end{array}$ \\
\hline & $\begin{array}{l}\text { pada "Rp" (reviewer } 1 \text { dan reviewer } 4) \\
\text { Seorang pedagang kue "Terang Bulan" }\end{array}$ & Seorang pedagang kue "Terang Bulan" \\
\hline & $\begin{array}{l}\text { yang sam lam ukuran yang berbeda. } \\
\text { harganya } R_{p}{ }_{30}, 00 \text {. Terang bulan }\end{array}$ & $\begin{array}{l}\text { yang sama dalam ukuran yang berbeda. } \\
\text { harganya Rp30.000,00. Terang bulan }\end{array}$ \\
\hline 3 & $\begin{array}{l}\text { Pada soal nomor } 2 \text {, gunakan situasi atau } \\
\text { konteks yang ada di daerah sekitar } \\
\text { (reviewer } 2 \text { dan reviewer } 3 \text { ) }\end{array}$ & $\begin{array}{l}\text { Mengubah situasi atau konteks dalam soal } \\
\text { menggunakan yang ada di daerah sekitar }\end{array}$ \\
\hline 4 & $\begin{array}{l}\text { Pada soal nomor 4, gunakan Bahasa } \\
\text { Indonesia yang baku dari kata "orange" } \\
\text { dan "pink" (reviewer 5) }\end{array}$ & $\begin{array}{l}\text { Mengubah kata "orange" menjadi } \\
\text { "jingga", dan kata "pink" menjadi "merah } \\
\text { muda" }\end{array}$ \\
\hline 5 & $\begin{array}{l}\text { Pasa soal nomor } 8 \text {, sebaiknya gambar } \\
\text { diperbaiki agar simetris dan sesuai } \\
\text { deskripsi dalam soal (reviewer } 4 \text { ) }\end{array}$ & $\begin{array}{l}\text { Memperbaiki gambar agar lebih simetris } \\
\text { dan sesuai deskripsi dalam soal nomor } 8\end{array}$ \\
\hline 6 & $\begin{array}{l}\text { Soal sudah sesuai untuk level mahasiswa, } \\
\text { dan perbaiki kalimat sesuai dengan } \\
\text { kaidah Bahasa Indonesia } \\
\text { reviewer) }\end{array}$ & $\begin{array}{l}\text { Memperbaiki kalimat sesuai dengan } \\
\text { kaidah Bahasa Indonesia }\end{array}$ \\
\hline
\end{tabular}

Kemudian soal literasi matematis prototipe 2 diujicobakan pada kelompok kecil (small group), yaitu 3 kelompok mahasiswa yang masing-masing terdiri dari 5 mahasiswa calon guru. Mahasiswa yang mengikuti tahap small group adalah mahasiswa semester 3. Kelompok pertama terdiri atas 3 perempuan dan 2 laki-laki, kelompok kedua perempuan semua, dan 
kelompok ketiga laki-laki semua. mahasiswa calon guru dalam setiap kelompok memiliki kemampuan matematika tinggi, sedang, dan rendah.

Tahap small group dilakukan untuk melihat kepraktisan soal literasi matematis yang dikembangkan (Disnawati \& Nahak, 2019). Dalam tahap ini, mahasiswa calon guru diminta untuk membaca dan menyelesaikan soal pada lembar jawaban yang disediakan. Selanjutnya mereka diminta untuk memberikan masukan terkait kesulitan dan kekurangan dengan menuliskan pada lembar komentar. Dari kelompok pertama, 4 mahasiswa calon guru menyatakan soal literasi matematis dapat dipahami maksud atau yang ditanyakan sedangkan 1 mahasiswa calon guru menyatakan kurang bisa memahami maksud soal nomor 2. Sedangkan dari kelompok 2, diketahui 3 mahasiswa calon guru menyatakan soal bisa dipahami, 1 mahasiswa calon guru menyatakan soal jelas, dan 1 mahasiswa menyatakan soal nomor 2 dan 5 kurang jelas. Kemudian kelompok 3, diketahui semua mahasiswa calon guru menyatakan soal jelas dan bisa dipahami. Secara umum mahasiswa calon guru dalam tahap small group menyatakan bahwa soal literasi matematis mudah dibaca dan dipahami. Kendala dan kekurangan yang terjadi selama pelaksanaan small group dijadikan sebagai bahan masukan untuk merevisi soal literasi matematis. Berdasarkan hasil perbaikan, diperoleh soal literasi matematis prototipe 3 .

Selanjutnya dilakukan tahap field test. Soal literasi matematis prototipe 3 diujicobakan kepada mahasiswa calon guru di Sidoarjo. Ada 34 mahasiswa calon guru di Sidoarjo yang mengikuti tahap field test. Soal literasi matematis yang dikembangkan ada sebanyak 12 soal dengan prediksi level soal 3, 4, 5, dan 6. Adapun konteks yang digunakan adalah pekerjaan (jual beli, mebel), pribadi (kegiatan belanja kebutuhan pokok, aktivitas sehari-hari bersama keluarga, aktivitas individu di sekolah), sains (kearifan lokal, transportasi, tumbuh-tumbuhan, desain bangunan), sosial (pertandingan, jual beli), sedangkan untuk konten ada kuantitas (kombinasi), bentuk dan ruang (lingkaran, segitiga siku-siku, kubus), perubahan dan hubungan (persamaan linear, persamaan dan pertidaksamaan linear), ketidakpastian dan data (diagram batang, aproksimasi, rata-rata).

\section{Pembahasan}

Pengembangan soal literasi matematis ini dilakukan dalam dua tahap yaitu preliminary study dan formative evaluation yang terdiri atas self-evaluation, expert review dan one-to-one, small group dan field test dengan melibatkan lima orang validator (empat guru besar pendidikan matematika dengan kepakaran dalam bidang literasi matematis dan satu doktor matematika) serta 34 mahasiswa calon guru matematika. Setelah melalui revisi dan uji coba baik di kelas 
kecil maupun kelas besar, soal literasi matematis yang dikembangkan telah memenuhi kriteria valid, paraktis dan efektif. Soal literasi matematis yang menggunakan konteks Indonesia berupa kearifan lokal merupakan hal yang baru bagi mahasiswa calon guru. Hal ini memberi dampak sangat postitif mereka karena konteks lebih mudah dibayangkan atau real dan bisa memudahkan mereka dalam pembentukan konsep.

Penelitian ini telah menghasilkan soal literasi matematis dengan kriteria baik dari segi validitas, kepraktisan dan keefektifan. Kevalidan soal literasi matematis yang dikembangkan ini dipenuhi berdasarkan validasi pakar secara kualitatif dari aspek konten (ketepatan atau kesesuaian materi yang digunakan dengan karakteristik soal literasi matematis dan kesesuaian materi soal untuk digunakan dalam mendukung matematisasi mahasiswa calon guru), konstruk (kalimat soal tidak menimbulkan penafsiran ganda, rumusan soal memakai kalimat perintah atau tanya, kemudahan dipahami, dan kejelasan batasan soal), penelaahan soal yang berhubungan dengan pemakaian bahasa Indonesia yang baik dan benar menurut Ejaan Yang Disempurnakan (EYD), yang meliputi penggunaan kalimat matematika yang benar dalam rumusan soal, penggunaan kaidah bahasa Indonesia yang baik dan benar, penggunaan kata-kata yang dikenal mahasiswa, dan rumusan soal yang komunikatif.

Soal literasi matematis yang dikembangkan dikatakan praktis karena memenuhi dua hal yaitu; para validator telah menyatakan bahwa soal literasi matematis yang dikembangkan dapat digunakan dan kenyataan menunjukkan bahwa pada tahap ujicoba small group dan field test, soal literasi matematis yang dikembangkan mudah dipakai dan dapat digunakan oleh mahasiswa calon guru. Soal literasi matematis berbasis kearifan lokal Indonesia yang dikembangkan dapat mendukung matematisasi mahasiswa calon guru. Selanjutnya, efektivitas soal literasi matematis yang dikembangkan ini dapat diindikasikan dari hasil belajar mahasiswa calon guru baik secara tertulis maupun secara lisan pada saat field test. Lebih dari $78 \%$ mahasiswa calon guru mencapai kriteria baik dan berdasarkan wawancara diketahui bahwa mahasiswa calon guru dapat mencapai indikator matematisasi ketika menyelesaikan soal literasi matematis. Penggunaan konteks Indonesia berupa kearifan lokal dalam mengembangkan soal literasi matematis merupakan hal baru bagi mahasiswa calon guru. Berdasarkan hasil observasi, penggunaan konteks ini mampu menumbukan sikap positif terhadap matematika dalam diri mahasiswa calon guru.

Sementara itu, penggunaan konteks dalam soal menjadi sangat penting dalam aktivitas matematisasi. Dengan menggunakan konteks, bisa diketahui kemampuan mahasiswa calon guru dalam mentransformasikan soal dunia nyata ke dalam simbol-simbol. Lebih lanjut, penggunaan konteks sangat penting dalam soal literasi matematis karena sesuai pendapat 
(OECD, 2013, 2016) bahwa dengan mengunakan konteks bisa diketahui kemampuan mahasiswa calon guru dalam mengidentifikasi aspek matematika menggunakan objek pembelajaran matematika.

\section{Penggunaan Soal Literasi Matematis dalam Mendukung Matematisasi Mahasiswa Calon}

\section{Guru}

Berdasarkan hasil analisis jawaban mahasiswa calon guru dan hasil wawancara, contoh aktivitas matematisasi yang dilakukan mahasiswa calon guru adalah sebagai berikut.

1. Menyajikan aspek matematika yang diketahui dalam bentuk deskripsi verbal

Mahasiswa calon guru menyajikan aspek matematika yang diketahui dalam soal menggunakan deskripsi verbal dengan cara menuliskan sebagian data yang diketahui pada soal (Lestariningsih et al., 2018b). Dia menuliskan kata-kata "Diketahui TB kecil dengan D $30 \mathrm{~cm}$ harganya 30.000, TB besar dengan D $40 \mathrm{~cm}$ harganya 40.000" seperti ditunjukkan dalam Gambar 3.

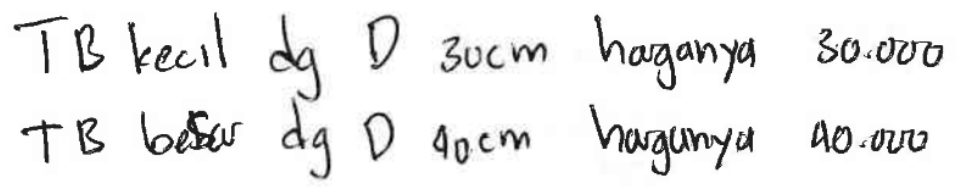

Gambar 2. Deskripsi Verbal

2. Mengidentifikasi fakta, konsep, prinsip, atau prosedur yang terdapat dalam soal konteks dunia nyata

Mahasiswa calon guru mengidentifikasi fakta, konsep, prinsip, atau prosedur yang terdapat dalam soal konteks dunia nyata dengan menyebutkan ukuran diameter dan harga dari terang bulan kecil dan terang bulan besar (Gambar 2). Hal ini sesuai dengan pandangan yang dikemukakan OECD (2016) dan de Lange (1987) bahwa dalam merumuskan soal konteks dunia nyata ke dalam soal matematis, seseorang melakukan aktivitas mengidentifikasi aspek matematika dalam permasalahan yang terdapat pada situasi konteks nyata dan memahami aspek-aspek dari soal yang berhubungan dengan fakta, konsep, prinsip, atau prosedur yang terdapat dalam soal awal.

3. Memvisualisasikan fakta, konsep, prinsip, atau prosedur menggunakan pemodelan

Mahasiswa calon guru memvisualisasikan fakta, konsep, prinsip, atau prosedur menggunakan pemodelan dengan cara menyatakan terang bulan menjadi "TB" dan diameter menjadi "D” (Gambar 2) dengan berkata, “TB itu singkatan dari Terang Bulan kalau D diameter...”. Selain itu, dia juga menggunakan huruf "T" untuk menyatakan terang bulan (Gambar 3). Hal ini sesuai dengan pendapat Niss (2010) yang menyatakan 
matematisasi adalah proses representasi suatu masalah nyata ke dalam bentuk matematis (pemodelan).

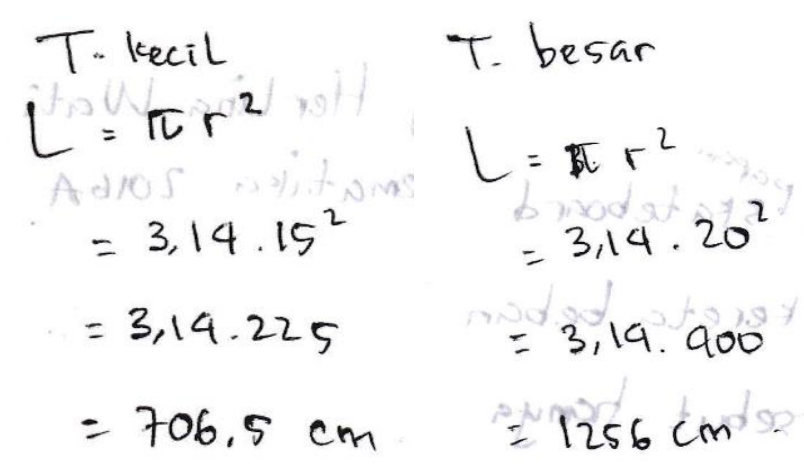

Gambar 3. Visualisasi fakta, konsep, prinsip, atau prosedur

4. Menggunakan atau membangun fakta, konsep, prinsip, atau prosedur atau penalaran matematis untuk memeroleh solusi matematis

Mahasiswa calon guru menggunakan atau membangun fakta, konsep, prinsip, atau prosedur atau penalaran matematis untuk memeroleh solusi matematis (Roux, 2010). Dia membangun fakta dengan menggunakan simbol untuk menyatakan terang bulan dan diameter. Selanjutnya dia menggunakan konsep lingkaran untuk menyatakan terang bulan menggunakan prinsip rumus luas lingkaran untuk menentukan terang bulan yang lebih murah, dan menggunakan prosedur algoritma perkalian dalam menghitung luas lingkaran, serta algoritma pembagian ketika membandingkan harga terang bulan besar dan terang bulan kecil (Gambar 3 dan Gambar 4).

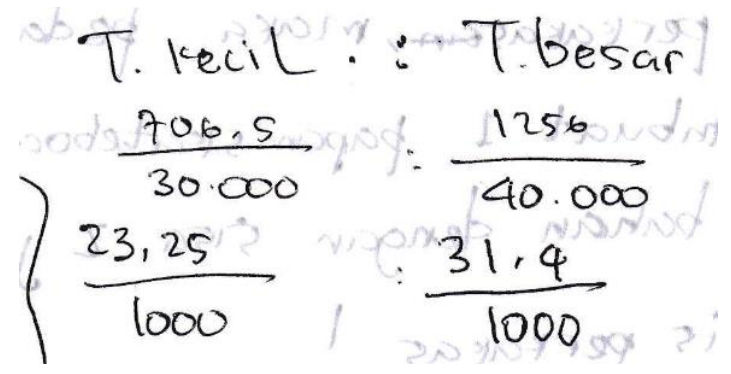

Gambar 4. Algoritma Pembagian

5. Menafsirkan solusi matematis ke dalam konteks dunia nyata pada soal awal

Mahasiswa calon guru menafsirkan solusi matematis ke dalam konteks dunia nyata pada soal awal dengan cara merefleksikan solusi matematis yang diperoleh dengan soal situasi nyata (OECD, 2006). Mahasiswa calon guru menafsirkan solusi matematis ke dalam konteks dunia nyata pada soal awal dengan menyatakan bahwa harga terang bulan yang 
lebih murah adalah terang bulan besar (Gambar 5). Hal ini sejalan dengan hasil wawancara, mahasiswa calon guru menyatakan "Jawaban saya terang bulan besar lebih murah".

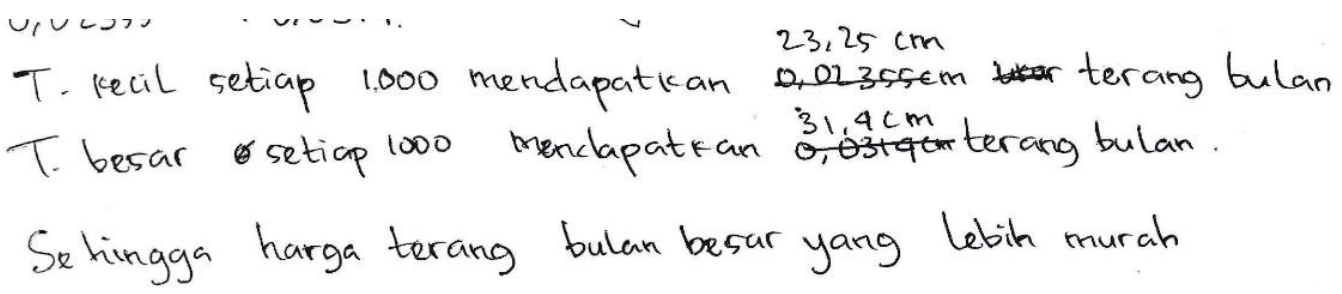

Gambar 5. Menafsirkan solusi

6. Mengevaluasi kesesuaian antara solusi matematis dalam konteks masalah dunia nyata

Mahasiswa calon guru mengevaluasi kesesuaian antara solusi matematis dalam konteks masalah dunia nyata dengan menyatakan permasalahan yang terdapat dalam soal. Hal ini sesuai dengan pandangan yang dikemukakan (OECD, 2013, 2016) bahwa dalam mengevaluasi solusi soal melibatkan aktivitas menyatakan kesesuaian antara solusi matematis dalam konteks masalah dunia nyata. Kemudian mahasiswa calon guru menyebutkan ukuran terang bulan besar dan terang bulan kecil yang diperoleh jika seseorang membeli terang bulan dengan harga yang sama. Data yang diperoleh tersebut kemudian dibandingkan sehingga diketahui terang bulan yang harganya lebih murah.

\section{Simpulan}

Penelitian ini telah menghasilkan 12 soal literasi matematis menggunakan kerangka PISA dengan konteks Indonesia yang valid, praktis, dan memiliki efek potensial. Soal literasi matematis yang dikembangkan terdiri atas dua soal dengan konteks pekerjaan, empat soal dengan konteks pribadi, empat soal dengan konteks sains, dan dua soal dengan konteks sosial. Soal literasi matematis dengan level tiga ada empat soal, level empat ada empat soal, level lima dan enam masing-masing ada 2 soal Kevalidan soal literasi matematis diketahui berdasarkan hasil penilaian validator, kepraktisan dari hasil uji coba small group. Sedangkan efek potensial terlihat dari hasil tes, yaitu $78 \%$ mahasiswa calon guru masuk kategori baik. Hal ini berarti soal literasi ini dapat digunakan untuk mendukung mahasiswa calon guru dalam melakukan aktivitas matematisasi, mulai dari aktivitas mengubah soal konteks dunia nyata ke dalam soal matematika sampai aktivitas memformulasikan soal matematika menjadi penyelesaian matematis dengan menerapkan sejumlah aturan yang sesuai dengan matematika, termasuk menafsirkan solusi matematis ke dalam konteks soal. Berdasarkan temuan yang diperoleh, maka dapat dilakukan penelitian lanjutan tentang pengembangan soal literasi matematis untuk 
mendukung kemampuan komunikasi mahasiswa calon guru karena komunikasi merupakan salah kemampuan dasar yang penting dalam menyelesaikan soal literasi selain matematisasi.

\section{Referensi}

Abdullah, S. S. (2015). Mahasiswa (Calon) Guru Matematika yang Profesional. Seminar Nasional Matematika Dan Pendidikan Matematika UNY 2015, 1(Pendidikan Matematika), 721-726.

Biccard, P., \& Wessels, D. (2015). Student mathematical activity as a springboard to developing teacher didactisation practices. Pythagoras, 36(2), 1-9. https://doi.org/10.4102/pythagoras.v36i2.294.

Biccard, P., \& Wessels, D. (2017). Developing Mathematisation Practices in Primary Mathematics Teaching through Didactisation- Based Teacher Development. African Journal of Research in Mathematics, Science and Technology Education, 21(1), 61-73. https://doi.org/10.1080/18117295.2017.1283184.

de Lange, J. (1987). Mathematics, insight and meaning. Utrecht: OW\&OC.

Disnawati, H., \& Nahak, S. (2019). Pengembangan Lembar Kerja Siswa Berbasis Etnomatematika Tenun Timor pada Materi Pola Bilangan. Jurnal Elemen, 5(1), 64. https://doi.org/10.29408/jel.v5i1.1022.

Gravemeijer, K. P. E. (1994). Developing realistic mathematics education. Faculty of Sciences, Freudenthal Institute, 13(3), 200 pp. Retrieved from http://www.cdbeta.uu.nl/tdb/fulltext/199503terwel2.pdf\%0Ahttp://www.fisme.science.uu.nl/toepassingen/20014/

Lange, Jan de. (2006). Mathematical Literacy For Living From OECD-PISA. Tsukuba Journal of Educational Study in Mathematics, 25(September), 13-35.

Lestariningsih, L. Amin, S.M., Lukito, A., \& Lutfianto, M. (2017). Mathematisation of female student teachers with high mathematics ability in solving mathematical literacy problem with personal context. Proceeding of the 1st Mathematics, Informatics, Science, and Education International Conference (MISEIC) 2017.

Lestariningsih, L., Amin, S. ., Lukito, A., \& Lutfianto, M. (2018a). Mathematisation of Preservice Teacher in Solving Higher Order Thinking Problem. 160(Incomed 2017), 291-294. https://doi.org/10.2991/incomed-17.2018.62.

Lestariningsih, L., Amin, S. M., Lukito, A., \& Lutfianto, M. (2018b). Students' Mathematisation in Solving Mathematical Literacy Problems with Space and Shape Contents. Journal of Physics: Conference Series, 1108(1), 0-7. https://doi.org/10.1088/1742-6596/1108/1/012083.

Mahfudhoh, R., Susanto, \& Trapsilasiwi, D. (2017). Pengembangan Soal Pelevelan Literasi Matematika Konteks Personal untuk Siswa Kelas VIII SMP. Kadikma, 8(3), 58-67.

Niss, M. (2010). Modeling a crucial aspect of students' mathematical modeling. Modeling Students' Mathematical Modeling Competencies: ICTMA 13, 43-59. https://doi.org/10.1007/978-1-4419-0561-1_4.

OECD. (2006). Assessing Scientific, Reading and Mathematical Literacy. In Assessing Scientific, Reading and Mathematical Literacy. https://doi.org/10.1787/9789524858366fi.

OECD. (2013). PISA 2012 Assessment and Analytical Framework MAtheMAtIcS, ReAdIng, ScIence, PRobleM SolvIng And FInAncIAl 1IteRAcy. In Echinoderms: Durham Proceedings of the 12th International Echinoderm Conference. https://doi.org/10.1201/9780203869543-c92.

OECD. (2016). PISA 2015 Assessment and Analytical Framework. In Evolution. 
https://doi.org/10.1787/9789264255425-en.

Patnani, M. (2013). Upaya Meningkatkan Kemampuan Problem Solving pada mahasiswa. Jurnal Psikogenesis, 1(2), 185-198.

Pulungan, D. A. (2014). Pengembangan Instrumen Tes Literasi Matematika Model PISA. Journal of Educational Research and Evaluation, 3(2), 74-78. https://doi.org/10.33627/sm.v3i2.259.

Roux, S. (2010). Forms of Mathematization ( 14th-17th Centuries ). Early Science and Medicine, 15, 319-337. https://doi.org/10.1163/157338210X516242.

Stillman, G., \& Brown, J. P. (2014). Evidence of implemented anticipation in mathematising by beginning modellers. Mathematics Education Research Journal, 26(4), 763-789. https://doi.org/10.1007/s13394-014-0119-6.

Tessmer, M. (1993). Planning and Conducting Formative Evaluations: Improving the Quality of Education and Training. In Kogan Page. https://doi.org/10.1177/026142949901400115.

Winter. (2013). Mathematics content or contextual understandings: Issues of primacy in South African mathematical literacy classrooms. In Papanikos, G.T. (Ed.),. Proceedings of the Seventh Annual International Conference on Mathematics Education \& Statistics Education, Mathematics and Statistics. Athens, Greece.

Zulkardi. (2006). Formative Evaluation: what, why, when and how. Oocities. Retrieved from http://www.oocities.org/zulkardi/books.html

Zulkardi, \& Putri, R. (2010). Mendesain sendiri soal kontekstual matematika. Prosiding KNM13 Semarang, 1-7. 